\title{
SONG AND MOVEMENT AS MEDIA OF EARLY CHILDHOOD LANGUAGE DEVELOPMENT
}

\author{
Warananingtyas Palupi $^{\text {I), Ruli Hafidah }}{ }^{2}$ ), Karsono ${ }^{3}$ ) \\ PG PAUD FKIP UNS \\ palupi@staff.uns.ac.id
}

\begin{abstract}
The early childhood learning should cover many aspects of development, ranging from religious and moral values, social, emotional, cognitive, physical motor, linguistic and artistic. Song and Movement are still identified with motion. Early childhood learning is synonymous with singing, clapping and playing while active. Motion and song activities are very tightly attached and can not be separated, especially in providing learning to young children. Motion and song learning is an activity in playing while learning and learning through playing, so activities performed through motion/movement and song are expected to please the child as well as touch the development of language, sensitivity to the rhythm of music, motor development, confidence, and the courage to take risks. Through motion or movement and song, children learn to develop their linguistic ability, it is through listening song dan music rhythm, children develop their receptive ability in language. And children' expressive ability in language is developed while children sing the song. Therefore, it is necessary for an activity that can train early childhood educators in giving stimulation to children through motion and song.
\end{abstract}

Keywords: song, movement, language development, early childhood

\section{GERAK DAN LAGU SEBAGAI MEDIA PENGEMBANGAN BAHASA AUD}

\begin{abstract}
Abstrak: Pembelajaran PAUD harus mencakup berbagai aspek pengembangan, mulai dari Nilai Agama Moral, sosial emosional, kognitif, fisik motorik, bahasa, dan seni. Gerak dan lagu masih diidentikkan dengan bidang pengembangan fisik motorik. Pembelajaran AUD identik dengan nyanyian, bertepuk tangan dan bermain sambil bergerak aktif. Kegiatan gerak dan lagu sangat melekat erat dan tidak dapat dipisahkan terutama dalam memberikan pembelajaran kepada anak usia dini. Pembelajaran gerak dan lagu merupakan sebuah kegiatan dalam belajar melaui bermain atau belajar seraya bermain, sehingga aktivitas yang dilakukan melalui gerak dan lagu diharapkan akan menyenangkan anak sekaligus menyentuh perkembangan bahasa, kepekaan akan irama musik, perkembangan motorik, rasa percaya diri, serta keberanian mengambil resiko. Melalui gerak dan lagu anak belajar mengembangkan kemampuan bahasa mereka, yaitu melalui mendengarkan dan menyimak lagu dan irama musiknya anak mengembangkan kemampuan bahasa reseptif. Sedangkan kemampuan berbahasa ekspresif dikembangkan ketika anak mau menyanyikan lagu tersebut. Oleh karena itu perlu adanya suatu kegiatan yang dapat melatih para pendidik anak usia dini dalam memberikan perangsangan pada anak melalui gerak dan lagu.
\end{abstract}

Kata Kunci: lagu, gerak, pengembangan bahasa, anak usia dini

\section{PENDAHULUAN}

Pembelajaran gerak dan lagu adalah bernyanyi dan latihan gerak tubuh yang sangat berhubungan erat, karena irama lagu dapat mempengaruhi dan mengendalikan pusat syaraf. Sehingga cara belajar yang baik bagi anak adalah melalui lagu dan gerakannya. Pembelajaran melalui gerak dan lagu yang dilakukan sambil bermain akan membantu anak untuk lebih mengembangkan kecerdasannya tidak hanya pada aspek pengembangan seni, bahasa dan fisiknya saja tetapi juga pada pengembangan emosional dan kognitif anak (Frigyes Sandor, 1975 : 4) [1]. 
Penggunaan lagu anak-anak dalam dunia pendidikan anak usia dini (PAUD) sudah sangat umum dilakukan di berbagai negara. Penggunaan lagu tersebut tentu tidak lepas dari fungsi penting lagu dalam mengembangkan kecerdasan anak pada masa tumbuh kembangnya. Studi yang dilakukan Portowitz dan Klein (2007) menjelaskan bagaimana program musik di kelas PAUD mampu memperbaiki proses perkembangan kognitif anakanak, bahkan pada anak-anak dengan kesulitan belajar [2].

Pengenalan gerak dan lagu anakanak sejak dini dapat memberikan dampak yang penting bagi pengembangan kecerdasan musikal dan kinestetis di usia selanjutnya. Kegiatan gerak dan lagu sangat melekat erat dan tidak dapat dipisahkan terutama dalam memberikan pembelajaran kepada anak usia dini. Pembelajaran gerak dan lagu merupakan sebuah kegiatan dalam bermain seraya belajar dan belajar melaui bermain dan aktivitas yang dilakukan melalui gerak dan lagu diharapkan akan menyenangkan anak sekaligus menyentuh perkembangan bahasa, kepekaan akan irama musik, perkembangan motorik, rasa percaya diri, serta keberanian mengambil resiko.

Para ahli saraf memastikan bahwa lagu, gerakan dan permainan dengan musik pada kanak-kanak merupakan salah satu aktivitas neurologis yang bagus untuk memperkenalkan pola bicara, keterampilan sensori-motor dan kemampuan gerak vital. Anak kecil sangat tertarik jika musik menggunakan lagu, gerak, emosi dan permainan (Carol Crees 2010: 2) [3].

Melalui pembelajaran gerak dan lagu juga dapat meningkatkan kecerdasan kinestetik untuk menggunakan salah satu kemampuan mental dalam mengkoordinasikan gerakan tubuh. Kemampuan ini dapat dirangsang melalui gerakan tubuh, tarian dan olah raga yang berhubungan dengan koordinasi tubuh, keseimbangan, kekuatan, kelincahan dan koordinasi mata dengan tangan dan kaki. Karena itu perlu adanya suatu kegiatan yang dapat melatih para pendidik anak usia dini dalam memberikan perangsangan pada anak melalui gerak dan lagu.

Anak usia dini dalam melakukan sesuatu gerakan cenderung memiliki karakteristik sebagai berikut:

1. Menirukan, dalam upaya pengembangan kreativitas gerakan bahwa dalam bermain anak senang menirukan sesuatu yang dilihat. Anak dapat menirukan gerakan-gerakan yang dilihat baik secara langsung dari lingkungan maupun orang-orang sekitarnya maupun dari televisi, berdasarkan tema maupun gerakan-gerakan binatang yang diamati.

2. Manipulasi: anak-anak secara spontan menampilkan berbagai gerakan-gerakan dari obyek yang diamatinya.

Ada beberapa hal yang perlu diperhatikan untuk dapat memberikan gerak dan lagu yang sesuai dengan karakteristik anak usia dini yaitu:

1. Tema

Pada umumnya anak-anak selalu menyenangi hal-hal yang pernah mereka lihat. Anak akan menirukan nyanyian dan gerakangerakan yang sesuai dengan apa yang pernah mereka dengar dan lihat. Oleh karena itu guru harus menggunakan tema-tema sederhana yang ada disekitar anak. Oleh karena itu gerak-gerak yang pernah dilihat dan diamati oleh anak maka dapat dijadikan suatu tema nyanyian. Tema-tema yang pada umumnya disenangi oleh anak-anak TK 
diantaranya adalah tingkah laku binatang seperti: kucing, ikan, burung, kupu-kupu, kelinci, dan lain-lain.

2. Bentuk Gerak

Bentuk gerak yang sesuai dengan karakteristik anak-anak, pada umumnya adalah gerak-gerak yang dilakukannya tidaklah terlalu sulit, sangat sederhana sekali dan diulang-ulang. Mengingat pada dasarnya imajinasi anak TK tinggi dan mempunyai daya kreativitas yang tinggi serta anak-anak yang pada dasarnya senang bergerak. Oleh karena itu bentuk-bentuk gerak yang biasa dilakukan adalah bentuk gerakangerakan yang lincah, cepat, dan seakan menggambarkan kegembiraan mereka.

\section{Bentuk Iringan}

Dilihat dari karakteristik anak yang senang bergerak dengan gembira, anak TK biasanya menyenangi musik iringan yang menggambarkan kesenangan dan kegembiraan, terutama lagu-lagu anak yang mudah diingat, misalnya: lagu kelinciku, kebunku, kupu-kupuku, balonku, dan lain sebagainya.

Menurut Kamtini dan Husni (2005:80) bahwa secara keseluruhan dapat dikatakan bahwa karakteristik gerakan-gerakan anak usia dini adalah:

1. Bersifat sederhana

2. Bersifat maknawi dan bertema, artinya tiap gerak mengandung tema tertentu.

3. Gerak anak menirukan gerak keseharian orang tua dan juga orang yang berada di sekitarnya.

4. Anak juga menirukan gerak-gerak binatang [4].

Sedangkan karakteristik lagu untuk anak-anak usia dini sebagai berikut:

1. Nada/bit: fun (menyenangkan dan lucu), tidak terlalu keras dan tidak terlalu cepat (tidak seperti music rock). Anak-anak menyukai lagu yang energik dibanding dengan lagulagu yang temponya lambat.

2. Lirik: mudah dipahami anak-usia dini sehingga lirik menggunakan kata-kata yang sederhana dan tidak terlalu panjang (terutama lagulagu yang mengandung nilai pendidikan dan moral), boleh panjang asalkan mengandung sebuah cerita yang menarik dan mudah dipahami anak-anak, dan memiliki kata-kata yang berbobot.

3. Tema lagu: mengandung pesan moral yang berguna bagi anakanak (kebaikan, persahabatan, kerajinan, dll) dan mengandung nilai pendidikan (sarana mempermudah anak-anak untuk belajar tentang sebuah materi/tema tertentu (misalnya, lagu balonku: belajar tentang warna).

4. Atraktif: bisa mengajak anakanak untuk bergerak (menari, olah raga, bertepuk tangan dan menggerakkan bagian tubuh mereka).

Pengamatan pada proses pembelajaran di beberapa PAUD di Kecamatan Bendosari Kabupaten Sukoharjo Jawa Tengah, memperlihatkan bahwa penggunaan lagu anak-anak sangat dominan pada aktivitas mengawali pembelajaran, di tengah pembelajaran, dan pada saat menjelang pulang. Artinya lagu memiliki fungsi penting dalam pembelajaran anak usia dini (AUD). Sesungguhnya dalam gerak dan lagu bukan hanya kecerdasan musikalkinestetik yang berkembang, namun juga mencakup kecerdasan lain yang terintegrasi dalam diri anak, salah satunya adalah stimulasi kemampuan bahasa.

Bahasa adalahan alat penghubung atau komunikasi antara anggota masyarakat yang terdiri dari individu-individu yang menyatakan pikiran, perasaan, dan keinginan baik secara verbal maupun visual (Bromley, 1992) [5]. Pengembangan kemampuan berbahasa untuk anak usia dini merupakan salah satu aspek penting. Hal ini terjadi karena pada masa usia dini perkembangan 
kemampuan berbahasa sangat cepat, dan kemampuan berbahasa merupakan bagian penting dalam proses berpikir, dan mengekspresikan ide-ide anak, serta mengkomunikasikannya dengan orang lain. Di samping itu kemampuan berbahasa merupakan alat dalam mengakses dan mengolah pengetahuan yang diperoleh anak.

Para tokoh aliran Konstruktivistik berpandangan bahwa keterampilan berbahasa dan berpikir anak terbentuk ketika anak berinteraksi dan merespon lingkungannya (Seefeldt dan Nita B, 1994) [6]. Melalui interaksi dengan lingkungannya, anak membentuk suatu aturan untuk berkomunikasi dengan lingkungannya. Perkembangan berbahasa anak mengikuti tahap-tahap berpikir anak mulai dari tahap sensorimotor, praoperasional, operasional kongkrit dan operasional formal. Bahkan Vigotsky (Morrow, 1993) menekankan bahwa pengalaman berbahasa anak terbentuk ketika anak berinteraksi dengan lingkungan sosialnya (orang-orang yang ada di sekitarnya) [7]. Dari pandangan tersebut dapat diartikan bahwa perkembangan berbahasa anak banyak ditentukan oleh kualitas interaksi anak dengan lingkungannya. Melalui interaksi anak dengan lingkungannya, akan diperoleh pengetahuan dan keterampilan berbahasa. Oleh karena itu orang-orang dewasa perlu memfasilitasi pemerolehan bahasa anak dengan menyediakan lingkungan yang kondusif, misalnya memberikan kesempatan kepada anakuntuk lebih banyak berinteraksi dengan lingkungan sosial anak.

Seefeldt dan Nita B (1994) mengemukakan bahwa pada umumnya perkembangan bahasa anak usia adalah sebagai berikut; (1) Perkembangan bahasa terjadi dengan sangat cepat (2) Pada usia 3 tahun anak berbicara secara monolog dan 4 tahun menguasai 90\% phonetik dan sintaksis tetapi masih sangat umum. (3) Anak sudah mampu terlibat dalam percakapan dengan anak atau orang dewasa lainnya. (4) Di awal usia 5 tahun anak sudah memiliki perbendaharaan kata sebanyak kira-kira 2500 kata. (5) Anak masih sering mengalami kesulitan mengucapkan huruf $1, \mathrm{r}$, sh. (6) Anak sering salah mengerti tentang kata- kata dan digunakan sebagai humor. (7) Anak menjadi pembicara yang tidak putus-putus [8].

Ahli lain yaitu Patmonodewo (1995) mengemukakan bahwa perkembangan berbahasa anak secara bertahap berubah, dari sekedar melakukan ekspresi suara saja ke berekspresi dengan berkomunikasi, dan dari hanya berkomunikasi dengan menggunakan gerakan dan isyarat untuk menunjukkan kemauannya, kemudian berkembang menjadi komunikasi melalui ujaran yang jelas dan tepat. Lebih lanjut, Patmonodewo menyatakan bahwa anak telah mampu mengembangkan keterampilan berbicara melalui percakapan yang dapat memikat orang lain [9]. Mereka menggunakan bahasa dengan berbagai cara misalnya dengan bertanya, berdialog, berbicara untuk mengekspresikan perasaan dan ideidenya atau mendeskripsikan suatu benda, dan peristiwa yang diamatinya, serta bernyanyi.

Dari kedua pendapat tersebut dapat disimpulkan bahwa perkembangan bahasa anak terjadi sangat cepat. Kemampuan berbahasa anak dapat diaktualisasikan dengan berbagai cara, yakni berkomunikasi dengan orang lain untuk mengekspresikan ide, gagasan, bendabenda dan peristiwa yang dialaminya. Anak dapat menggunakan bahasa melalui dialog, bertanya dan bahkan bernyanyi serta bergerak mengenai apa yang ingin disampaikannya. Di samping itu daya serap anak mengenai bahasa sangat tinggi, karena mereka ingin membentuk 
perbendaharaan kata yang tidak terkira jumlahnya. Oleh karena itu, peran lingkungan sangat membantu perkembangan bahasa anak.

\section{HASIL DAN PEMBAHASAN}

Berdasarkan pengamatan pembelajaran di PAUD di Kecamatan Bendosari Kabupaten Sukoharjo, metode lagu dan gerak (song and movement) merupakan metode pembelajaran yang paling sering digunakan dalam pembelajaran. Metode tersebut dapat diterapkan pada semua waktu pembelajaran, baik di bagian awal (pembiasaaan dan apersepsi), bagian inti, maupun bagian akhir pembelajaran (review pembelajaran). Pembelajaran gerak dan lagu biasanya menimbulkan kesan bermakna bagi anak dan anak akan lebih mudah mengingat materi pembelajaran yang diberikan oleh guru. Kebermaknaan pembelajaran gerak dan lagu akan memberikan dampak positif yaitu mengembangkan berbagai kecerdasan anak. Selain itu, dengan menggunakan gerak dan lagu dalam pembelajaran di PAUD memiliki banyak manfaat dan tujuan. Salah satunya untuk mengembangkan kemampuan berbahasa atau kecerdasan lingustik anak.

Dalam pembelajaran yang menggunakan lagu dan gerak pada dasarnya anak mengembangkan kemampuan berbahasa lisan mereka. Kemampuan bahasa lisan anak akan berkembang baik dalam bentuk kemampuan bahasa reseptif dan kemampuan bahasa ekspresif. Hal ini sesuai dengan Permendikbud Nomor 146 tahun 2014 tentang Kurikulum 2013 Pendidikan Anak Usia Dini pada indikator pencapaian perkembangan anak usia dini sampai usia 6 tahun pada aspek bahasa tentang memahami bahasa reseptif (menyimak), menunjukkan kemampuan berbahasa reseptif (menyimak), memahami bahasa ekspresif (mengungkapkan bahasa secara verbal dan non-verbal), dan menunjukkan kemampuan berbahasa ekspresif (mengungkapkan bahasa secara verbal dan non-verbal) [10]. Sedangkan pada aspek seni terdapat indikator melakukan aktivitas seni sederhana (misal menggerakkan tubuh ketika mendengar musik dan bernyanyi).

Mendengarkan lagu merupakan kemampuan bahasa reseptif yang penting, karena dengan mendengarkan lagu diperlukan dalam "menerima bahasa". Mendengarkan dalam hal ini bukanlah suatu kegiatan yang pasif tetapi sebaliknya mendengarkan atau bahkan menyimak menjadi suatu kegiatan yang aktif dan penuh tujuan. Di sekolah TK, dengan mendengarkan lagu anak-anak akan diajarkan untuk berusaha memahami isi lagu. Sekaligus dengan bernyanyi anak dapat menambah perbendaharaan kata-kata/kosakata baru karena pada waktu bernyanyi anak dapat mendengar dan menghafal kosakata baru. Selain daya ingat anak kuat untuk mengingat lirik-lirik lagu, anak juga mampu berpikir kritis. Hal ini sesuai dengan pendapat Campbell dalam Madyawati (2016: 141) yang mengatakan bahwa anak juga berpikir kritis untuk memahami makna yang terkandung di dalam lagu tersebut, sesuai dengan kehidupan nyata [11].

Dengan lagu dan gerak juga mengembangkan kemampuan bahasa ekspresif. Setelah anak-anak mendengarkan dan berusaha menghafal kata-kata yang ada dalam lirik lagu, anak akan diminta guru atau dengan sendirinya dapat mengucapkannya. Dalam hal ini mengucapkan kata-kata dalam sebuah lirik lagu seperti halnya 
berbicara kepada orang lain. Anak dapat menggunakan bahasa yang dia dengar dan mengucapkannya dengan memahami maksud dari kata yang diucapkannya melalui contoh yang didengar dan dilihatnya di lingkungannya. Ditambah dengan adanya gerakan dalam bernyanyi, akan memudahkan anak untuk menyampaikan maksud dari kata-kata yang diucapkan tersebut.

Menyanyikan lagu ditambah dengan adanya gerakan pada dasarnya merupakan kegiatan yang sangat digemari anak-anak PAUD karena dengan menyanyi dan diikuti gerak, anak bebas mengekspresikan dirinya baik dengan kerasnya suara ataupun ketepatan kata-katanya. Campbell \& Dollaghan dalam Madyawati (2016:141) menyebutkan bahwa bernyanyi juga merupakan ekspresi berbahasa. Sambil bernyanyi anak dapat bergaya sesuka hatinya dan mengucapkan kata-kata yang dia sukai dalam lagu yang dinyanyikannya. Dengan seringnya seorang anak bernyanyi secara tidak langsung telah melatih olah vokal dan artikulasi anak.

Dengan menggunakan strategi bernyanyi, seorang anak akan terangsang perkembangannya serta mudah berinteraksi dengan lingkungannya. Hal ini sesuai dengan hasil penelitian Khorida dalam Madyawati (2016:142) yang telah membuktikan bahwa strategi bernyanyi dapat mengembangkan pengetahuan dan keterampilan:

1. Melatih kepekaan rasa dan emosi.

2. Melatih mental anak untuk mencintai keselarasan, keharmonisan, keindahan, dan kebaikan.

3. Mencoba mengungkapkan isi dan maksud perasaan.

4. Meningkatkan kemampuan mendengar pesan dan menyelaraskan gerak dengan lagu yang didengar.
5. Menggunakan kemampuan mendengar dengan mengamati sifat dan watak lagu.

6. Meningkatkan kepekaan terhadap isi dan pesan nyanyian

Lagu-lagu yang digunakan dalam mengembangkan kemampuan berbahasa anak diantaranya lagu balonku. Dari lirik lagu anak tersebut anak-anak diajarkan tentang mengenal warna, baik warna primer maupun warna sekunder. Hal ini karena di setiap topik pembelajaran anak baik kelompok A maupun kelompok B akan selalu diminta untuk mengidentifikasi warnanya. Dengan lagu balonku diharapkan anak-anak semakin mengenal warna dan dengan objek balon merupakan benda yang disukai anak. Setelah mendengarkan dan menyanyikan lagu balonku tersebut disertai gerakan anak-anak diminta untuk menceritakan atau mengungkapkan isi lagu balonku tersebut. Dalam hal ini anak dikembangkan kemampuan berbahasa reseptif dan ekspresifnya sekaligus.

Pada lagu kelinciku, anak-anak belajar tentang binatang kelinci. Guru mengajarkan tema binatang dengan sub tema binatang kesayangan dan dengan topik kelinci. Pada pembelajaran sesuai kurikulum 2013, guru bisa memulai pembelajaran dengan memperdengarkan atau menyanyikan lagu kelinciku. Dengan lirik lagu tersebut guru bisa meminta anak mendengarkan (mengembangkan kemampuan berbahasa reseptif) dan mengidentifikasi binatang kelinci. Dengan lagu tersebut anak juga bisa menjelaskan cara bergerak kelinci dengan melompat sehingga anakanak juga bisa melakukan gerakangerakan seperti kelinci yang senang melompat. 
Lagu sayonara atau good bye dapat digunakan pada akhir pembelajaran. Dengan lagu tersebut anak-anak mengetahui bahwa setelah mereka belajar di sekolah sehari itu, tiba saatnya mereka harus berpisah dan berharap bisa berjumpa kembali esok hari untuk belajar kembali di sekolah. Anak-anak sebenarnya tidak hanya sekedar menyanyi saja tetapi juga diminta untuk menceritakan isi lagu. Dengan menceritakan isi lagu anak mengembangkan kemampuan berbicara dan mengkomunikasikannya kepada teman-temannya.

\section{SIMPULAN}

Anak-anak usia dini pada dasarnya menyukai kegiatan menyanyi dan bergerak. Oleh karena itu, pembelajaran di PAUD juga menggunakan nyanyian/lagu dan gerakan untuk membelajarkan anak berbagai hal. Gerak dan lagu yang diterapkan dalam pembelajaran di PAUD ternyata memiliki banyak manfaat bagi anak. Berbagai kecerdasan anak melalui gerak dan lagu juga ditingkatkan. Salah satunya untuk mengembangkan kecerdasan lingustik anak. Dengan kata lain, gerak dan lagu dapat digunakan sebagai media pengembangan bahasa anak, yaitu bahasa lisan anak. Dalam gerak dan lagu, anak belajar mengembangkan kemampuan berbahasa reseptif dan ekspresif sekaligus. Sehingga kemampuan dan kreativitas serta inovasi guru dituntut untuk bisa menciptakan berbagai gerak dan lagu dalam membelajarkan berbagai hal kepada anak.

\section{DAFTAR PUSTAKA}

[1] Sandor, Frigyes. (1975). 9 Penerapan Gerak dan Lagu. Lembang: P2PNFI Jayagiri.

[2] Portowitz, A., \& Klein, P. (2007). Misc-Music: a music program to enhance cognitive processing among children with learning difficulties. International Journal of Music Education, 25, 259-271.

[3] Crees, G., Crees, C., Robinson, E. (2010). Songs from around the world: for young children. Australia: Gary and Carol Crees Publisher.

[4] Kamtini, \& Husni W., T. (2005). Bermain melalui gerak dan lagu di taman kanak-kanak. Jakarta: Departemen Pendidikan Nasional.

[5] Bromley, K., D. (1992). Language arts: exploring connections (2nd ed). Boston: Allyn and Bacon.

[6] Seefeldt, C., \& Nita, B. (1994). Early childhood \& education: an introduction. New York: Mc. Millan.

[7] Morrow, L., M. (1993). Literacy development in the early years, helping children read and write. Boston: Allyn and Bacon.

[8] Seefeldt, C., \& Nita, B. (1994). Early childhood \& education: an introduction. New York: Mc. Millan College Publishing.

[9] Patmonodewo, S. (1995). Buku ajar pendidikan prasekolah. Jakarta: Departemen Pendidikan dan Kebudayaan Direktorat Jenderal Pendidikan.

[10] Depdiknas. (2014). Peraturan Menteri Pendidikan dan Kebudayaan Nomor 146 Tahun 2014. Jakarta: Depdiknas.

[11] Madyawati, L. (2016). Strategi pengembangan bahasa pada 
Early Childhood Education and Development Journal

ISSN 2684-7442

1]

https://jurnal.uns.ac.id/ecedj

anak. Jakarta: Prenadamedia

Group. 